\title{
The Coordinative Development of Contemporary Private International Law*
}

\author{
Shiping $\mathrm{Lu}$ \\ School of Politics and Administration \\ Chang'an University \\ Xi'an, China 710064
}

\begin{abstract}
The history of private international law is a history of continuous coordination in many aspects of private international law. Private international law has experienced three stages: ancient, modern and contemporary. The ancient stage pursued certainty, predictability and international consistency, while the modern stage pursued fairness and flexibility. The contemporary stage is the coordination of the ancient and modern stages, the essence of which is the coordination and compromise of the legal value, and the manifestation is the coordination between the different kinds of conflict norms, the coordination between the certainty and flexibility of the conflict norms, the coordination between the multiple objectives of the judicial decision and the coordination between the pluralistic legislative methods. In the future, the development of private international law is consistent with the development of society.
\end{abstract}

Keywords-contemporary private international law; conflict norms; legal attributes; judicial objectives; legislative methods; coordination

\section{INTRODUCTION}

Since the bourgeoisie established its rule in the West, the rule of law as the fundamental method of governing the country has been universally accepted. In particular, the practice of running a modern country under the rule of law shows that the modern rule of law has an extremely distinct value orientation, which is often closely related to many modern values, such as democracy, human rights, equality, etc., the existence of modern and traditional values, etc, which make people worship the rule of law. However, the diversity of legal value leads to a variety of conflicts between legal values and the formation of value rank; the formation process of value rank is the process of coordinated development of value. The coordination of legal value is especially prominent in the foreign-related laws of various countries, private international law is one of them. In private international law, the coordination of abstract legal value goals is often reflected by the coordination of the internal elements of legal norms, legal attributes, judicial objectives and legislative usage methods. The study of the harmonious development of contemporary private international law has profound theoretical and practical value for understanding the complexity of the influence of the

*Fund projects: National Social Science Foundation Project (project approval No.: 14FFX047) ; Project supported by the National Student Aid Fund (project approval number: CSC201406565041). legislative factors of contemporary private international law, the contradiction of legal norms and the dilemma of judicial objectives.

\section{THE ESSENCE OF THE DEVELOPMENT OF}

CONTEMPORARY PRIVATE INTERNATIONAL LAW IS THE COORDINATION OF ORDER AND JUSTICE

In the history of private international law, (Private International Law is generally called conflict of laws in AngloAmerican Law system, but they are different in the continental law system and the Anglo American law system. Except for the special explanation, this article only studies the conflict law in the international private law of the continental law system.) The private international law has entered the contemporary private international law era since the middle of the 20th century. Compared with the ancient private international law before the nineteenth century and the modern private international law from the nineteenth century to the middle of the twentieth century, the contemporary private international law is not perfect, but it is quite mature in vertical comparison. It absorbs the beneficial experience of the development of private international law before, and more importantly, it removes the different extremes of private international law in different times before, thus showing great coordination.

In jurisprudence, legal value is not only systematic (refers to the diversity of value), but also has diversity (refers to the difference of value). It is gratifying to note that the current study of legal value in our country has developed from the pure theoretical abstract study of jurisprudence to the parallel study of applied jurisprudence and judicial practice. As far as jurisprudence and applied jurisprudence are concerned, the terms of legal value used by them are different, the former has universality and the latter has particularity. For example, in private international law, the value of private international law is expressed as the realization of foreign policy, the establishment of a new international economic order, and the simplification of judicial tasks, the predictability and consistency of judgment results and the fairness of specific cases. [1] There are also studies of the development of private international law from the point of view of formal and substantive justice. [2]In fact, a detailed investigation will find that the expression of legal value in the applied law is actually a variety of variations of legal value in the applied law. 
The expression of legal value in jurisprudence is very complicated and the most concise is the discussion by Professor Edgar Bodenheimer (Edgar Bodenheimer) a famous German-American legal philosopher. Although Professor Bodenheimer does not use the term "legal value (or value)" directly in the title of the chapter he writes (he uses the title "the Nature and function of the Law". In fact, he does not use the term "legal value or value" directly throughout the book), but he states in the text: "in a sound legal system, the two values of order and justice usually do not conflict; on the contrary, They tend to be closely connected at a higher level. The synthesis of these two values, as demanded by people, can be summed up in this sentence, that is, the law is designed to create a just social order. "[3] In fact, domestic jurisprudence generally believes that, Professor Bodenheimer regards order and justice as the value form of law. [4] Professor Zhou Yongkun has also summed up the value of law as the value of order and justice. [5] Taking order and justice as the values of law is concise and easy to understand. Professor Bodenheimer believes that the two basic concepts of understanding the formal structure of the legal system and its substantive purpose are order and justice. Order means that there is a certain degree of consistency, continuity and certainty in both natural and social processes. [6] it can be seen that order is the external formal structure of legal system. At the same time, the certainty, predictability and consistency of the judgment (hereinafter referred to as "the three characteristics of the judgment") are also the external forms of expression of the judgment. Thus, it can be seen that the pursuit of order as the external form of expression of the law, can objectively realize the external form of judgment, that is, the three characteristics of judgment. The pursuit of certainty, predictability and consistency is the goal and value of private international law. Therefore, the value of private international law in ancient times is order. As for justice, John Rawls (John Bordley Rawls), the contemporary American philosopher, studied it from the categories of substantive justice and formal justice, and Aristotle, the ancient Greek thinker, from the categories of correction justice (or corrective justice) and distributive justice. The author believes that formal justice and distributive justice belong to the same level of justice, the difference between the two is only a different perspective, formal justice emphasizes the universality and autonomy of the law; Distributive justice emphasizes the external manifestation of the result of application of law, that is, the three characteristics of judgment. In fact, substantive justice and correction justice are the justice, fairness, reasonableness and integrity pursued by the law after rectifying the relevant factors again. In fact, whether it is substantive justice or correction justice, they belong to different levels of justice with formal justice and justice in distribution justice. In view of this, Professor Shen Zongling, a famous jurist of our country, believes that these words can be said to mean the same, but the meanings are strong and weak, and the scope may vary. Therefore, the more appropriate words should be chosen in different situations. [7] it can be seen that, The value pursued by modern private international law (the fairness and rationality of individual cases) is actually justice. It may be easier to understand that the specific value of private international law can be raised to the general value of jurisprudence in the field of private international law.
In short, this paper argues that the value of private international law is order and justice. The value of ancient and modern private international law is only the different manifestations (also called concrete values) or variants of order and justice, which are highlighted in the ancient and modern stages. ${ }^{1}$

Private international law originated in Europe and formed ancient private international law, but it was initiated and promoted by the United States to form modern and contemporary private international law. From the history of the development of private international law, modern and contemporary private international law is indeed inherited and developed on the basis of ancient private international law. As Howard M. Holtzmann Professor of International Law, Lea Brilmayer and Jack Goldsmith, professor of law at the University of Chicago, commented on two restatements of conflict laws in the United States, "The first restatement provided considerable certainty and sacrificed fairness. The second restatement provides more flexibility and, consequently, more fairness, at the expense of certainty." [8] The two restatements of the conflict law clearly reflect the sharp change of the legal value of the conflict law from the first stage to the second stage. The first is to pursue order at the expense of justice, and the second to pursue justice at the expense of order. The American academic circles are not satisfied with these two restatements of conflict of laws, so the third restatement of conflict of laws was discussed at the annual meeting of the United States of America in 1999. In fact, the history of private international law is the history of the development of the legal value of private international law from the perspective of the legislative development of private international law in the world, while the development of private international law in the United States is concerned with the development of private international law, the change and coordination of its legal value is more extreme in a short period of one hundred years. Therefore, in general, the development of private international law is actually a process of constant coordination of legal value, which is clearly reflected in the development stage of contemporary private international law. Therefore, the value pursued by contemporary private international law is the harmony of order and justice; compared with ancient and

When discussing the legal value of ancient private international law, the scholars of private international law often refer to stability. In fact, there is no need to refer to stability as well as certainty. In the middle of the eighteenth century, Justice Hardwick (Lord Hardwicke), Chief Justice of the United States Federal Supreme Court, stated in Walton v.Tryon (21 Eng.Rep.262 < Chanc.1753 >): "certainty is the mother of stability (repose), so the goal of law is to achieve certainty." President of the Union of American Law Schools, "even Justice Hardwick did not raise stability above everything else," said Wilt Galen (Walter Gellhorn), a law professor at Columbia Law School, commenting on the claim. [Walter Gellhorn, the Legislative and] Administrative Response to Stability and Change, 17 Vanderbilt Law Review. In addition, Professor Yan Cunsheng, a jurist in China, holds that one of the three uses of certainty of law is the stability of certainty of law (Yan Cunsheng, ed., Jurisprudence, Law Press, 2007, p. 27) That is to say, after a certain law was created, it could not be changed for a relatively long period of time; at the same time, even if it was later revised, the new law and the old law should maintain some continuity. This shows that certainty has indeed covered stability, and in fact can achieve the purpose of stability. Therefore, what ancient private international law pursued is the certainty, predictability and consistency of judgment, so it is not necessary to establish the legal value of stability. 
modern private international law, contemporary private international law has achieved a better balance between order and justice.

This is a macro argument on the legal value orientation of contemporary private international law, that is, the development of contemporary private international law is a harmonious process of order and justice, and achieves a better balance between order and justice. The following will be further detailed microscopic investigation to further confirm the development of contemporary private international law of this macro-argument.

\section{CONTEMPORARY PRIVATE INTERNATIONAL LAW IS THE HARMONIZATION BETWEEN DIFFERENT KINDS OF CONFLICTING NORMS}

Since the emergence of private international law as a theoretical form in Italy in the 13th century, it has gone through two stages: ancient and modern. The drawbacks of private international law have become increasingly apparent. Various reforms have emerged, among which the most revolutionary one was the United States in the middle of the 20th century. In the $1950 \mathrm{~s}$, the most striking anti-traditional trend of thought in the history of private international law has emerged in the United States, [9] During the American Conflict Law Revolution, many new theories against the traditional Conflict Law were formed, which decided the applicable law mechanically regardless of the content of substantive law. Their essence was the choice between the norm of jurisdiction choice and the norm of content orientation. Therefore, from the perspective of jurisdictional choice norm and content-oriented norm, the following article analyzes the harmonization of the legal value of contemporary private international law

Under the provisions of traditional conflict norms (conflict norms are special names of legal norms in the field of private international law), judges have to choose only between the laws of a number of jurisdictions that may be applicable when considering specific cases; Since all legal complexes in each jurisdiction are in fact a legal system, the process of legal choice actually becomes a choice of only a number of legal systems. In the process of selecting several legal systems, the judge does not examine the actual substantive content of the applicable law (i.e. the applicable law) in the selected legal system. Therefore, the traditional conflict law critic David F. Cavers of the United States and other scholars first referred to the traditional conflict of law norms as "choice of jurisdiction" norm. [10] it can be seen that the traditional conflict norms have mechanical and blind shortcomings.

Critics of traditional conflict of laws in the American Conflict Law Revolution believe that only by examining the content of specific substantive private law in a number of relevant legal systems and further identifying its potential policies and interests can we make legal choices. Otherwise, legal choices cannot be rational. As a result, Professor Caffles believes that the process of choice of law must be reformed; courts should consider cases on the basis of the application of the private law of specific entities in a number of relevant legal systems, to determine which system of law should be chosen to apply. In other words, the specific substantive law in each legal system is applied first, and then the comparison of many judgments is made in detail, and the legal system that should be applied is decided on the basis of the result of the investigation. This process seems reasonable in theory, but it increases the judicial burden, and puts the cart before the horse and even becomes too subjective.

In terms of how to carry out this new concept in legislation and judicature, the judicature is more flexible. It can use many technical means to avoid the law that is unwilling to apply and finally apply the reasonable law; therefore, the judicature is more convenient. As a matter of fact, this new kind of contentoriented conflict of laws can also be formulated in legislation, and then the applicable law can be selected according to the contents of specific entity private law in some legal systems. However, it should be pointed out that this does not mean that the content-oriented specification will replace the jurisdiction choice norm in future legislation. Because the differences between the substantive laws of the various legal systems are still very large and frequently revised, it is neither possible nor realistic to formulate all of them as content oriented norms. Therefore, the content-oriented specification can only be the exception of jurisdiction choice in legislation. The core of contemporary private international law legislation is to coordinate the choice of jurisdiction norms with the content oriented norms to form a reasonable system of harmonious coexistence of the two, rather than consider how to reduce the former. In other words, the focus of private international law legislation should be eclecticism. The reason is that the jurisdiction choice norm and the content oriented norm embody different legal values, the former embodies the value contained in the ancient private international law, and the latter embodies the value contained in the modern private international law. The coordination of two conflicting norms embodying different legal values is the coordination of two kinds of legal values. Therefore, the legislation of contemporary private international law is the legislation to coordinate the legal value from the angle of making different specific legal norms. Furthermore, the value orientation pursued in the development of contemporary private international law is the coordination of legal value.

\section{CONTEMPORARY PRIVATE INTERNATIONAL LAW IS THE HARMONY BETWEEN CERTAINTY AND FLEXIBILITY OF CONFLICTING NORMS}

Certainty and flexibility are the basic attributes of law. In the development of private international law, how to realize the conflict norms with both certainty and flexibility has always been discussed by scholars of private international law from the perspective of jurisprudence. This paper continues to analyze the harmonization of the certainty and flexibility of contemporary conflicts of private international law.

From the basic attribute of law, on the one hand, the law needs to have certainty. The basic attribute of certainty of law makes law have the characteristics of predictability and consistency. But the certainty of law also makes the law itself rigid. The inflexibility of the law prevents the law from being adapted to suit it, so that in certain circumstances it can be made harmful. [11] Therefore, the law, on the other hand, also requires flexibility, that is, uncertainty. The starting point of 
the basic attribute of flexibility of law is to make the law produce justice and the solution of individual cases. The tension between the two basic attributes of legal certainty and flexibility has always been accompanied by the history of legislation. As Professor Ren é David, a French scholar, put it: "there are always two kinds of demands for justice that exist in all countries: on the one hand, the law must be certain and predictable; on the other, it must be flexible." "[12] Professor JOSEPH H.BEALE of Harvard University served as rapporteur for the first restatement of conflict of laws in the United States; after the publication of the restatement by the American Society of Law, Bill published his own monograph on conflict of laws. He pointed out with deep feeling: "the whole history of law is the history of alternately trying to make law more deterministic and flexible." [13] Its implication is that the development of private international law is no exception. This should also be Bill's own profound experience after years of in-depth study of the legal attributes of certainty and flexibility of conflicting norms in private international law.

In each jurisdiction, the contradiction between legal certainty and flexibility is resolved in the long history of legislation, and an appropriate balance is sought between the two contradictory objectives. In the 20th century, the legal system of private international law in the United States and Europe showed different periodic motion trajectories. American private international law developed from the absolute certainty before the conflict of laws revolution to the anarchy of the conflict law revolution and then to the conflict law revolution and its anarchy due to its absolute flexibility, so that the norms of conflict are abolished, the certainty that the law ought to be left unsettled, and that, in the ensuing mature period of mutual compromise and tolerance (i.e., the current period), there is more flexibility than before the revolution of the law of conflict, There is also more certainty than the conflict of laws revolution and later period. The relationship between legal certainty and flexibility has reached a new balance, with more emphasis on flexibility. European private international law has slowly and calmly moved from certainty to flexibility by drawing on new things, adopting old ones and abandoning outdated methods, introducing a small amount of manipulative flexibility, and eventually achieving a new balance in their relations, but there is a greater emphasis on certainty. It can be seen that the development of private international law in Europe and the United States has the same goals and objectives. In fact, the development process is a process of coordination between the certainty and flexibility of conflict norms, seeking a new balance, but with different emphasis.

\section{CONTEMPORARY PRIVATE INTERNATIONAL LAW IS THE COORDINATION BETWEEN THE PURSUIT OF INTERNATIONAL CONSISTENCY AND THE PROTECTION OF THE INTERESTS OF SPECIFIC JURISDICTIONS IN THE OBJECTIVES OF JUDGMENTS}

The aim of judicial decision is also an important aspect of private international law research, which is related to the development trend of private international law. Specifically, in private international law cases, whether to pursue the international consistency of judgments or to protect the interests of a particular jurisdiction has always been a subject of much discussion.
The ancient private international law theory regarded the pursuit of international consistency of judgments as one of the main objectives in the process of determining applicable law (that is, if cases were heard in different countries, (a number of its decisions are the same), but it is doubtful whether and to what extent they can be achieved, so that the theory and practice of modern private international law seek other objectives, such as achieving "substantive impartiality", another example is the protection of the interests of special jurisdictions (especially the seat of the court). Professor David F. Cavers and Professor Curry (Brainerd Currie), students of American conflict law scholar Bill, are the strongest and most powerful proponents of this view. Mr. Curry insists that the needs of the international system should not influence the choice of law. In applying the law of this jurisdiction, courts have the right and should apply the law of the place of courts, regardless of whether the jurisdiction has interests or not, except for certain less constitutional restrictions. From the point of view of the evolution of the objective of judicial judgment in private international law, from the pursuit of international consistency of judgment to the protection of the interests of specific jurisdictions, it is in fact the evolution process from ancient private international law to modern private international law.

In the history of private international law, both the legislation and the judicature of private international law believe that the pursuit of international consistency in judgments is a cold-blooded selection goal that has to be pursued with all one's heart, but may not always be pursued, so when we choose the law, we must consider the pursuit of other goals, but we must not damage the target. The pure doctrine of pursuing the interests of the special jurisdiction (the interests of the government) put forward by Corey was abandoned by the United States at the end of the twentieth century because it was at the expense of the pursuit of the goal of compromising the international consistency of judgments. However, some concepts should be retained, for example, it is a legitimate purpose to try to harmonize the interests of the relevant jurisdictions, and so on. In other countries this view has also been abandoned. Objectively speaking, no jurisdiction will pursue the interests of the jurisdiction as the primary goal of the choice of law, but only put it in a position in the sequence of the target system. This situation is no exception in the legislative judicature of statutory law.

Contemporary private international law merely balances to some extent the objective of international consistency of judgments pursued by ancient private international law and the objective of protecting the interests of special jurisdictions pursued by modern private international law, in other words, It is only a balance between the pursuit of different legal values, which is coordination. Therefore, from the point of view of the pursuit of international consistency of judgments and the need to protect the interests of special jurisdictions, the judicature of contemporary private international law is the one that coordinates the legal value, and furthermore, the value orientation pursued in the development of contemporary private international law is the coordination of legal value. 


\section{CONTEMPORARY PRIVATE INTERNATIONAL LAW IS THE HARMONIZATION BETWEEN PLURALISTIC LEGISLATIVE METHODS}

This paper makes a detailed study of the coordination of the legal value of contemporary private international law from three aspects: conflict norms, legal attributes and judgment objectives. In fact, they are the concrete manifestations of the coordination of the order and justice of the legal value of contemporary private international law. The choice of jurisdiction, the certainty of law and the international consistency of judgments are to realize the order value of law, and the content-oriented norm, the flexibility of law and the need to protect the interests of special jurisdictions are to realize the just value of law. From the legislator's point of view, the coordination of the three pairs of categories is actually the result of the legislators' use of multiple methods.

The legal norm is the form in which the legislator expresses the legal content, and it is the means for the legislator to embody the legal value and the guidance of the legislator through the legal content. Various methods in private international law are the research categories selected by scholars when studying conflict rules. In the 20th century, many changes have taken place in the private international law. In order to deal with many changes, in the aspects of the methods used, various countries generally use the "pluralistic method", that is, the unilateral conflict method, the bilateral conflict method and the substantive method. The method of jurisdiction selection is the category concluded by scholars when they study conflict norms according to their regional effects. Although it is now almost superseded in the United States by policy options, it remains dominant in other countries and adds a number of content orientation specifications to the jurisdictional selection methodology; at the same time, many content-oriented specifications are also selective, so contentoriented specifications are also called "result-oriented specifications". In fact, in the early twentieth century, the result-oriented norms have appeared, but are seldom used at that time. This shows that modern legislators should have recognized the need to restrict the orientation of "conflict justice"; at the same time, we should strengthen the "substantive justice" oriented legislation. In addition, the legislator also realized that substantive justice can only be used in the exceptional cases where the entity result is generally accepted, so it is rare that the use of substantive justice will cause controversy. It can be seen that many differences between US and European private international law are closely related to the responsibilities of judges and legislators in their respective legal systems. The United States mainly uses a pluralistic approach in the judicial process, so the way used is more subjective, more dramatic and more extreme, while the European continent adopts many systems in the legislative process, so the way used is more objective, more consistent and more restrained. The distinct characteristics of the two methods seem to indicate that there is a great difference between the two. In fact, the real difference between the two is not the substantive difference, but only the difference in degree.

It is a special mission of conflict norms in the 20th century to ensure a proper balance between certainty and flexibility. In the first half, the pursuit of the former was pursued at the expense of the latter; in the second half, the norms of conflict were completely abandoned in the United States, but they were still the main means of resolving conflicts of law in the vast majority of jurisdictions, Only conflict norms have been softened (weakened) both in legislation and in the judicial process. Some of the traditional conflict norms are through the innovation of judicial interpretation, others are to reformulate new norms. At the end of the twentieth century, people increasingly recognized and considered it necessary to pay attention to the flexibility of conflict norms, but it also struck a new balance between it and certainty, and did not bias too much towards certainty.

The same is true of the choice of law when considering the interests of the jurisdiction, considering that what is realized through justice is not normal and that what is achieved through legislation is normal; judge operation is one thing and legislator operation is another when it comes to identifying and weighing the interests of the jurisdiction. This is similar to that of Professor Curry, who argues that only legislators have the right to weigh regional interests, and judges do not. However, he believes that it is a contradiction in his view to empower judges to identify and clarify interests of jurisdiction, and then he thinks that judges have no right to compare and evaluate them. In the European law, legislators have the right to identify, weigh and choose for the interests of the law area. In fact, the differences between Europe and the United States are mainly due to their differences in the sources of law and the jurisdiction of judges; In the final analysis, the two legal systems (civil law system and common law system) formed under the influence of different historical conditions are caused by the differences in the mode of existence and the mode of operation. The continental law system has the characteristics of rational design and arrangement of all social relations, its code-style system is logical and rigorous, wide coverage, strong internal coordination and consistency, but in the face of extremely complex and constantly changing social relations, Sometimes it is too rigid to be fully adaptable. The tradition of the Anglo-American legal system, which emphasizes the solution of specific problems based on specific experience, is highly targeted and flexible, but its legal complexity, confusion and difficulty in being understood by nonprofessionals are also prominent. [14] But in any case, they are constantly adjusted to adapt to the development of the real society. Each of them may take on different forms, but the substantive results are almost the same.

In the development of contemporary private international law, the seemingly pursuit of pluralistic methods is not only the pursuit of unilateral conflict methods, but also the pursuit of bilateral conflict methods and substantive methods. Behind this is actually the pursuit of multiple values, that is, the coordination of legal values.

\section{CONCLUSION}

In a word, the development of contemporary private international law is the epitome of the whole history of private international law and the coordination and balance between ancient and modern private international law. In the history of the development of private international law, it has experienced an era of ancient private international law with 
excessive pursuit of order and a modern era of private international law with excessive pursuit of justice, at the end of the twentieth century, it entered the contemporary era of private international law with the goal of balancing, balancing and coordinating order and justice dynamically. On the whole, as far as private international law is concerned, whether in statutory law countries or case law countries, whether legislating or judicial, since the mid-twentieth century, the continuous adjustment and development of private international law to the end of the century, private international law has become very mature, adapted to the increasingly frequent and increasingly developed development of contemporary international exchanges, and laid a solid foundation for the future development of the legal system of private international law. It can be predicted that in the future private international law will be recoordinated and rebalanced on the basis of contemporary private international law in order to adapt to the continuous development of society.

\section{REFERENCES}

[1] Xiao Shuiping. Xiao Shuiping on conflict Law[M],Wuhan University Press, p. 315.

[2] Tan Yueqi. From formal Justice to substantive justice: Thinking of value transformation and development orientation of modern private international Law $[\mathrm{J}]$, Chinese Annual Journal of Private and Comparative Law, 1999.

[3] [America] Bodenheimer. Jurisprudence: legal philosophy and legal methods $[\mathrm{M}]$, Translated by Deng Zhenglai,China University of Political Science and Law press, 1999,p 319.

[4] Edited in chief by Liu Zuoxiang Jurisprudence [M],Social Science Literature Press, 2005, p471st, p474.

[5] Zhou Yongkun Jurisprudence-Global Vision [M], Law Press, 2000, p. 218.

[6] Same as [3] p. 219.

[7] Shen Zongling. Jurisprudence [M], Peking University Press, p 74.

[8] Lea Brilmayer \& Jack Goldsmith,Conflict of Laws : Cases and Materials, (CITIC PUBLISHING HOUSE 2003), p.333.

[9] Albert A. Ehrenzweig, A counter-revolution in conflicts law? From beale to cavers, 80 Harv.L.Rev. 377(1966).

[10] David F.Cavers,A CRITIQUE OF THE CHOICE-OF-LAW PROBLEM,47 Harv.L.Rev.,194(1933).

[11] France] Rousseau. Theory of Social contract(Also called: the principle of political rights.)[M](Version 2), Translated by $\mathrm{He}$ Zhaowu,Commercial press,1980,p163.

[12] [France] Rene. Davey. English Law and French Law: a substantive comparison $[\mathrm{M}]$,Tsinghua University Press, p. 33.

[13] JOSEPH H.BEALE, 1 A TREATISE ON THE CONFLICT OF LAWS,(BAKER,VOORHIS \& CO.1935),p.50.

[14] Zhang Wenxian, Jurisprudence [M] (second Edition), higher Education Press, 2003, p. 186. 